\title{
Pielonefrite em caprino - relato de caso
}

Rachel da Silva Batista, Rodrigo de Freitas Bittencourt, Tiago da Cunha Peixoto, Maristela de Cassia Seudo Lopes, Karina Medici Madureira'

Escola de Medicina Veterinária e Zootecnia, Universidade Federal da Bahia (UFBA), Salvador, BA, Brasil

*Autor correspondente

e-mail: karina.madureira@ufba.br

\section{Resumo}

Este trabalho teve como objetivo descrever os achados clínicos, necroscópicos e histopatológicos de um quadro de pielonefrite ocorrida em um animal da espécie caprina, macho, com quatro anos de idade. 0 animal era criado no quintal de uma casa localizada na região metropolitana de Salvador / BA. Sua dieta era composta por feno, frutas, ração para coelhos, carne de frango e biscoitos. 0 animal estava apático e inapetente, com dificuldade de urinar há cerca de oito dias, sendo verificada ainda a eliminação de sangue durante a micção. Este mesmo animal já havia sido internado previamente para tratamento de urolitíase obstrutiva. Ao exame físico observou-se coloração esbranquiçada das mucosas conjuntivas óculo-palpebrais e oral, com tempo de preenchimento capilar (TPC) de três segundos. Não foram verificados aumentos de volume na região prepucial ou peniana durante a inspeção, mas eliminação de grande quantidade de sangue vivo durante a micção. Os exames laboratoriais revelaram anemia normocítica normocrômica, trombocitopenia, linfopenia e eosinopenia, além de azotemia e aumento da atividade das enzimas hepáticas (AST e GGT). Foi instituída sondagem uretral e durante o procedimento avançou-se até a vesícula urinária, verificando-se apenas a presença de sangue vivo e alguns coágulos de sangue, sem volume considerável de urina. As alterações ultrassonográficas revelaram vesícula urinária com conteúdo anecogênico e pontos ecogênicos em suspensão, sem evidências de cálculo, e aparentava não possuir conteúdo urinário em seu interior. Ambos os rins apresentaram ecogenicidade moderadamente elevada e ecotextura pouca a moderadamente mais grosseira do que o normal. A pelve renal do rim esquerdo estava discretamente dilatada. Durante a realização do exame ultrassonográfico o animal apresentou piora no quadro clínico, vindo a óbito. Ao diagnóstico necroscópico os principais achados foram hipovolemia, grave hemoperitôneo, hematoma sublombar intraabdominal focalmente extenso, cirrose hepática incipiente e severa pielonefrite hemorrágica bilateral. Ao diagnóstico histopatológico, os principais achados foram pielonefrite grave, cirrose hepática micronodular, 
moderada esteatose hepática. Foi determinada como causa mortis choque hipovolêmico, causado por um intenso hemoperitônio. A anemia normocítica normocrômica e a trombocitopenia podem ser explicadas pelo quadro de hemorragia intensa e produção inadequada de eritropoietina devido ao quadro inflamatório dos rins. O hemograma revelou ainda bastonetes acima dos valores de normalidade, linfopenia e eosinopenia, característicos de uma condição inflamatória. As enzimas hepáticas estavam acima dos valores normais de referência para espécie, o que pode ser explicado pelo quadro de cirrose, contribuindo para a diminuição da produção hepática dos fatores de coagulação, agravando o quadro hemorrágico. Como o animal já havia sido atendido previamente e diagnosticado com urolitíase obstrutiva, provavelmente causada pelo manejo dietético inadequado, pode-se concluir que a pielonefrite manifestada pelo caprino aqui relatado poderia estar relacionada com aumento da pressão intravesical causado pelos urólitos, promovendo estase da urina e proliferação bacteriana. 